\title{
Marketing Mechanism of Consumer Demand for Ecological Products Identification
}

\author{
Uliana A. Pozdniakova ${ }^{1}$, Larisa V. Ponomareva ${ }^{1}$, Viacheslav U. Lapshin ${ }^{2}$, Alexey V. Bolotin ${ }^{3} \&$ Galina A. \\ Khmeleva $^{4}$ \\ ${ }^{1}$ Volgograd State Technical University, Volgograd, the Russian Federation \\ ${ }^{2}$ Tambov State University named after G.R. Derzhavin, Tambov, the Russian Federation \\ ${ }^{3}$ Ural stock market Institute, Yekaterinburg, the Russian Federation \\ ${ }^{4}$ Samara Academy of State and Municipal Management, Samara, the Russian Federation \\ Correspondence: Uliana A. Pozdniakova, Volgograd State Technical University, 28, Lenin Avenue, Volgograd, \\ 400005, the Russian Federation. Tel: 7-917-846-2391. E-mail: wua@list.ru
}

Received: September 2, 2014 Accepted: September 22, 2014 Online Published: November 14, 2014

doi:10.5539/ass.v10n23p123 URL: http://dx.doi.org/10.5539/ass.v10n23p123

\begin{abstract}
In the global economy, causing the inefficient use of natural resources, the development of industry production of genetically modified foods and the reduction of quality agricultural land, info propaganda against the deteriorating environmental situation becomes larger and modern society increasingly focuses on improving the quality of life of the population. The current socio-economic situation encourages Russian companies to develop new environmentally-oriented approaches to the organization of marketing activities.

But in Russia, the institutional environment of the Russian market does not allow environmentally-oriented enterprises to introduce new marketing tools, i.e. it is characterized by inadequate perfect the legal framework governing the interaction of all stakeholders in this market. Including Russia not adopted legislation on environmental labeling, and therefore extend unfair environmentally-oriented advertising and eco-branding enterprises, industrial and commercial activity which often does not respond positional enterprises environmental performance of products. Despite the lack of development of the institutional environment of the market, production and sale of organic products as a relatively advanced segment of the markets of developed foreign countries and is the premium segment of the market of developing countries, including in Russia. Due to the increasing environmental food crises of the last decade, increasing worries about the harm of genetically modified products, the expansion of state initiatives environmentally-oriented production and trade, Russia's WTO accession is obvious very promising development of the market of organic products in Russia. However, tools of marketing activities of Russian eco-oriented businesses are also not worked either theoretically or practically. Recognized only need environmental responsibility before society, and formal areas and forms of its realization are virtually absent.

The relevance of the study is due to the need of development of methods and tools for environmental marketing as a condition for the development of domestic enterprises competitiveness. The article deals with environmental marketing as a tool to control consumer preferences through a marketing mechanism to identify consumer demand for environmental products and a set of tools to promote products based on the greening of business (office space, product, business principles). The authors propose methods of marketing and statistical research of consumer preferences in the market, the use of which allows you to effectively perform market objectives to promote the national environmental products in the regional market, and it is filled with a variety of quality products and competitive child, primarily Russian-made, and create export potential to exit to electronic foreign market.
\end{abstract}

Keywords: demand, consumer preferences, earth-friendly products, environmental marketing, management, monitoring, small business

\section{Introduction}

In Russia, the environmental needs of both the needs of higher level, compared with material or other types of demand, the scale of individual and social preferences have moved into the background due to dissatisfaction 
with the material and social needs. Decline in living standards has led many Russian consumers to abandon the usual level of consumption and to reduce their requirements to a minimum. Most of the population follows a functional model of consumption, mindless consumption (Leonard, 2010). Conscious choice of organic products refers to the model of the trend of consumption, which has become a part of their traditional way of life. For this reason, environmental marketing tools will be needed for the development of the market for environmental products. Therefore, Russian enterprises should actively use the tools of environmental marketing in entering the world market, as the global market environmental factor is taken into account by enterprises in development strategies. In the Russian market environmental factor still does not fulfill such a role, as the demand for organic products has small volumes, to assess which is not possible because there is no official statistics on this market. You can only rely on the private study of Russian specialists. So spent in St. Petersburg in 2008, the study found that nearly $53 \%$ of respondents pay attention to the presence of the sign on the packaging, certifying product safety for health and the environment. For $48 \%$ of St. Petersburg care about their health and care for the environment is the most important factor that they are guided by purchasing environmentally friendly products. Interestingly, in a similar survey in 2006 the most important factor was named the care of their health (Anon, 2013).

In the transition from traditional marketing to environmental changes play a key role in information systems and communications (Anon, 2009). Formation of any development strategy using tools of environmental marketing is based on the identification of new issues, market trends and the state of science and technology (Budanov, 2013). Without market research it is impossible to get accurate information about effective marketing policy. Since environmental marketing is aimed at integrating environmental considerations into business activities, without accurate information about the effects of the firm and its competitors on the environment, on consumer attitudes towards eco-oriented companies and products on their preferences and lifestyle, it cannot be implemented.

In a continuous flow of information it is necessary to get all elements of the system of environmental marketing, especially life-cycle analysis, environmental audits and environmental impact assessment. Information on the environmental effectiveness of the company as a whole is the basis for making marketing decisions. In this regard, an environmentally-oriented businesses need in the marketing of environmental information that will allow them to move from a random, natural to the systematic process of gathering and processing information. Such information systems would create opportunity for managers to make effective decisions and be a database of information on requests of market-partners. They should be used to support marketing objectives and marketing strategy. Ultimately, the goals and the strategy should be consistent with the objectives of sustainable development through the use of environmental management techniques and strategies. This correspondence is in a developing concept of environmental marketing will be carried out by all subjects self-regulated marketing system of environmental information and communications.

\section{Materials}

This article uses material obtained in the course of the authors of marketing research. In this case, the authors have identified ways to solve problems, develop plans and methods of marketing research, formulated the subject of study and object of research.

As primary sources of information were used original studies, based on a survey of support groups. Support groups are typically used to verify the results of mass surveys. Data collection through surveys support groups provides an opportunity to obtain more objective information, as it removes the negative effect of mass screening, which is expressed in a large number of interviewees who are trying to appear more true than they really are (Borodin, 2014).

Secondary information was obtained from the publications of trade and industry associations, trade journals, publications devoted to environmental issues, magazines and newspapers to consumers, trade unions materials, annual reports and surveys, market review. Secondary sources allow you to create a useful reference library in the enterprise and to generate information on the tendencies of the market. Market research on the state of the market and consumer preferences plays important role for the media. Unfortunately, the Russian market for environmental marketing research there is a demand, but they have not yet received their development.

\section{Subject Area Description}

Marketing research is an integral part of the environmental marketing, presenting an analytical direction and focusing on the solving of practical problems. However, research results are the basis for the process control (Volosatova, 2014). 
Marketing mechanism for identifying demand is a regular collection and analysis of media marketing, information on consumer behavior, attitudes and intentions. Consumers are the external environment, which deals with their general characteristics. Calculation and measurement of the observed dynamics parameters allow generate events for the restructuring of the complex environmental marketing.

General marketing information systems are described in detail in the prior art of marketing. Accordingly, the system marketing environmental information can be regarded as part of the overall system, which generates a flow of information about one of the factors marketing environment.

Environmental Certification Center is seen as a marketing decision and environmental labeling - as a means of integrated marketing communications initiated by the marketing department. If a certificate is understood environmental affiliation environmental image of the company, the initiators should act PR-department and / or the Board of Directors (Kharkov, 2014). Elaborating on these findings, we add, no matter at what level the decision on environmental certification, at the strategic or technical, the implementation of that decision is carried out by employees of the marketing department.

Environmental marketing is the modern concept of entrepreneurship. The success of the company is directly related to consumer behavior, which is acquiring the goods, affects the position of the company on the market, being the source of his income (Dahlstrom, 2010). The consumer is the object of control. Control is not as such the consumer, and the ratio of consumer to the product, the desire to purchase the product and sales goals, in terms of the act of purchase. Through the negotiation of capabilities and needs of potential consumers demand generated. And in environmental marketing for marketing management means the management of demand (Kotler, 2007).

\section{Method}

Information flows related to monitoring, it flows to the medium of marketing and consumer behavior. Thus, monitoring demand for ecological products through market research is a priority element of the entire marketing mix (Grant, 2007). Even if the company has not clearly defined the boundaries of their marketing mix, the method of monitoring consumer demand must be developed. This does not necessarily independently develop this technique, and you can refer to marketing agencies (Akopova, 2013).

As a validation of the proposed findings, this approach is applied to a particular enterprise, namely the Internet-shop of children's goods «Galaktiika.ru». The mission of this commercial enterprise is "All that is necessary for the mother and baby, we will deliver at a convenient time for you! And the process of selection of goods will be for you easy and enjoyable. "

Medium-term objectives, it is advisable to put that trade enterprise «Galaktiika.ru», are as follows: 1 Ensure that the range of products consisted only of high quality and competitive children's production (100\%), primarily of Russian production, which will be included in the content of the Strategy development of children's products industry for the period up to 2020 . Now on the Russian market is dominated mostly imported goods, the share ranges from $60 \%$ in the segment of children's cosmetics and products for babies up to $90 \%$ in the segment of children's shoes, clothing and toys; 2 Create the export potential (up to 20-30\%) to exit for electronic foreign market.

As a means of achieving these objectives is proposed environmental marketing as a set of tools to promote products based on the greening of business (office space, product, business principles) (Popkova, 2014). But before you start to realize this idea, it is necessary to monitor the current target market, and at the moment is the regional market, the geography of which - Volgograd district.

The methods of marketing analysis in the study of selected theoretical direction of statistical analysis are selection, grouping, classification, analysis of the relationship and multivariate analysis (Tinyakova, 2013). The content of the proposed research methodology identified areas of marketing research, following which you can carry out your market objectives. We identified four stages in the process of organizational marketing research: the development of the general concept of specific research, development plan and research methodology, research, presentation of the results.

(1). Development of a common vision:

1.1). Tendencies. Considering children's products as a product, we can say that this product is currently very controlled product of the state, as the sphere of the production of children's products is a particular area that remained without proper attention to a certain stage of social transformation in Russia; 
1.2). The problem of the study is as follows: - the lack of an established reliable infrastructure market and as a consequence of the lack of quality, certified products on the Russian market of children's goods;

1.3). Solutions to the problem - the introduction of instruments of environmental marketing.

1.4). The object of study - the person of the female sex, aged 18 to 30 years, since it is this category of people is of strategic importance for business in the market of children's goods. Firstly, the most appropriate age for giving birth about 18 to 30 years, according to the Ministry of Health. Namely for this target audience is directed business online store «Galaktiika.ru». Secondly, even if at this age girls aged from 18 to 30 years old are not planning a pregnancy, it is this group of people in the medium term will present a unique target audience.

1.5). Subject of research - to identify the factors shaping consumer behavior in the market of organic products, the attitude of modern mass consumers to producers, the relationship of consumers and producers in the market, the level of environmental awareness of the Russian population

(2). Develop a plan and methods of marketing research: 2.1 development of the questionnaire, the questionnaire; 2.2 choice of study; 2.3 The scheduling of the study; 2.4 determination of quota sampling studies - 400 people (sex - female, health care - yes, the maintenance of health - a healthy diet).

(3). Study.

(4). Presentation of the results.

\section{Results}

We analyze the relationships and multivariate analysis of the results obtained in the course of marketing research.

Number of respondents girls aged from 18 to 30 years, health-conscious, is $64 \%$. The other girls (34\%) to the question "Do you Take care of your health?". Almost all answered in the negative. Only $2 \%$ of the respondents answered in the negative women, as reflected in Figure 1.

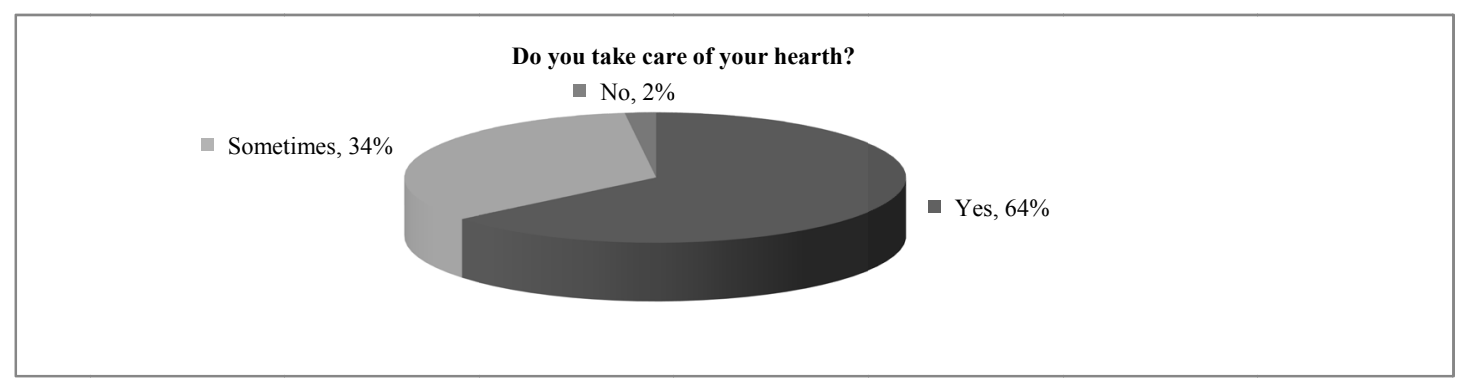

Figure 1. Answers to girls aged 18 to 30 years to the question "Do you Take care of your health?", \%

Answers to the question "What is enough, in your opinion, to maintain health in great shape?". Reflects the pattern $286 \%$ of girls said that to maintain health in great shape enough to exercise regularly. $84 \%$ of those surveyed women believe that to maintain health in great shape must also follow a healthy diet. That is, respondents in answering the question referred to more than one answer, and regular exercise and a healthy diet. It can be concluded that the sports-oriented girls choose healthy foods.

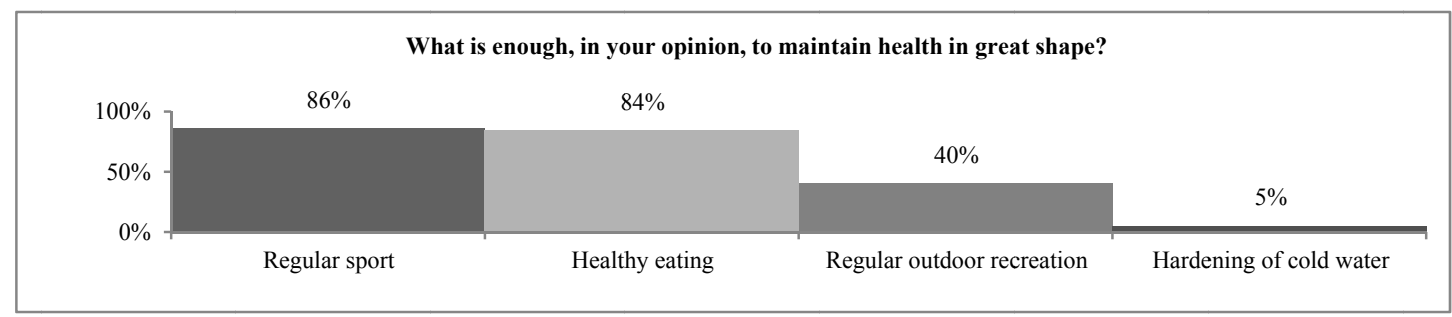

Figure 2. Answers to girls aged 18 to 30 years to the question "What is enough, in your opinion, to maintain health in great shape?", \% 
The question "What measures do you personally to be healthy?" Is open, and when you answer it, there were different responses, which can be seen in Figure 3 is interesting for our study is to answer "Do not eat foods that contain GMOs", only 2\% of respondents pay attention to environmental factors in the selection of products for your diet. Yet $40 \%$ of respondents polled quality feed in order to maintain good health.

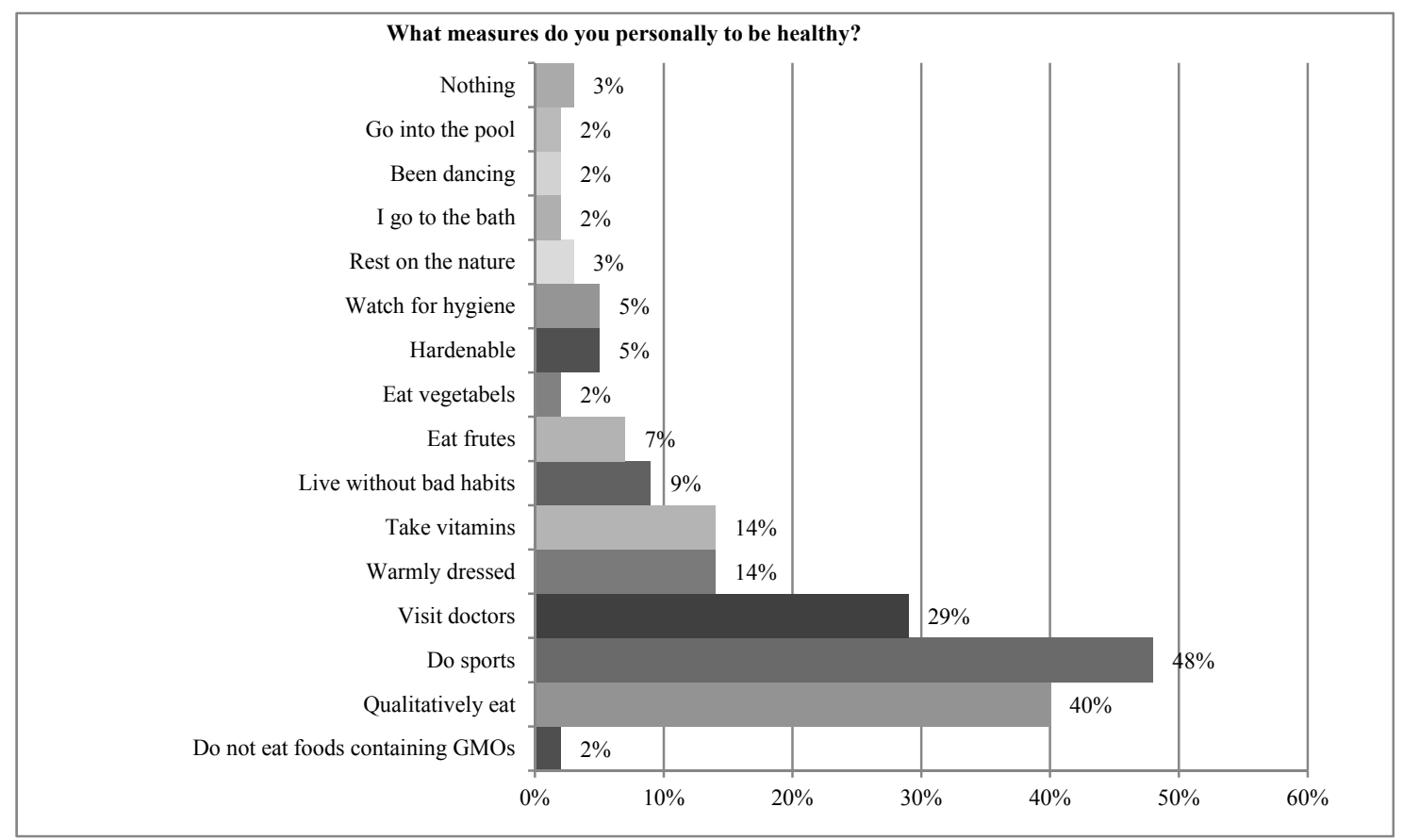

Figure 3. Answers to girls aged 18 to 30 years to the question "What measures do you personally to be healthy?", \%

The next question to consider is, "What do you mean by the concept of "healthy eating"? What associations do you come from? ". Responses to this question were as follows in Figure 4 "balanced diet" - $60 \%$ "quality food" $40 \%$, "the power of environmentally friendly products" - $28 \%$, "vegetarian food" - $0 \%$. When answering this question sounded own answers that are not listed in the questionnaire: "foods without additives and dyes" - 5\%, "food home-made food" - $2 \%$, "the daily use of liquid hot dish" $-2 \%$. The answer is "no food additives and dyes" is valuable for us, which shows the importance of naturalness used products, though, and for a small number of respondents, because naturalness is the main feature of ecological products. Also, the responses showed that $28 \%$ of respondents "healthy eating", associated with environmental products, so you can definitely use the environmental factor in the promotion of food to children.

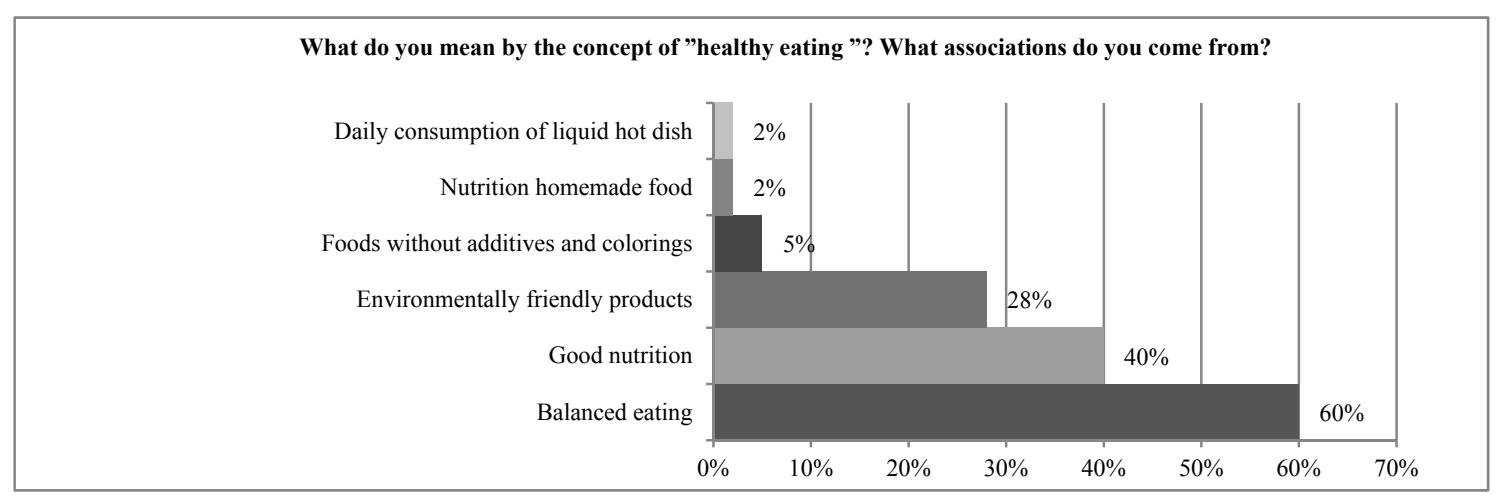

Figure 4. Answers to girls aged 18 to 30 years, the question "What do you mean by the concept of "healthy eating "? What associations do you come from?", \% 
Open-ended question, "Do you pay attention only to the quality of food, or as to the quality of other products? If yes, what? "Responses were received, as reflected in Figure 5, as" the quality of products "- $10 \%$. The remaining $90 \%$ of respondents pay attention to the quality of other products. And $10 \%$ of respondents only pay attention to the quality of the food. Thus, $10 \%$ of respondents pay attention to the quality of all products, $10 \%$ - only on the quality of food and the remaining $80 \%$ concerned about the quality of food products and some other products (cosmetics, clothes, shoes, electronics, medicine, machinery, household chemicals, hygiene products, perfumes, household items). All the results can be analyzed in Figure 6.

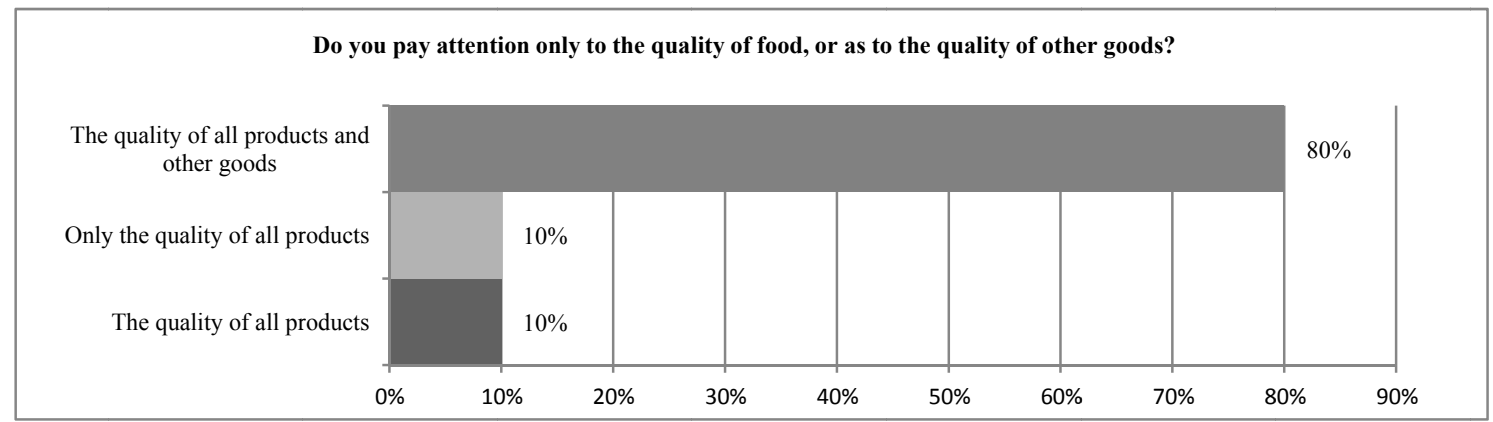

Figure 5. Answers to girls aged 18 to 30 years to the question "Do you pay attention only to the quality of food, or as to the quality of other goods?", $\%$

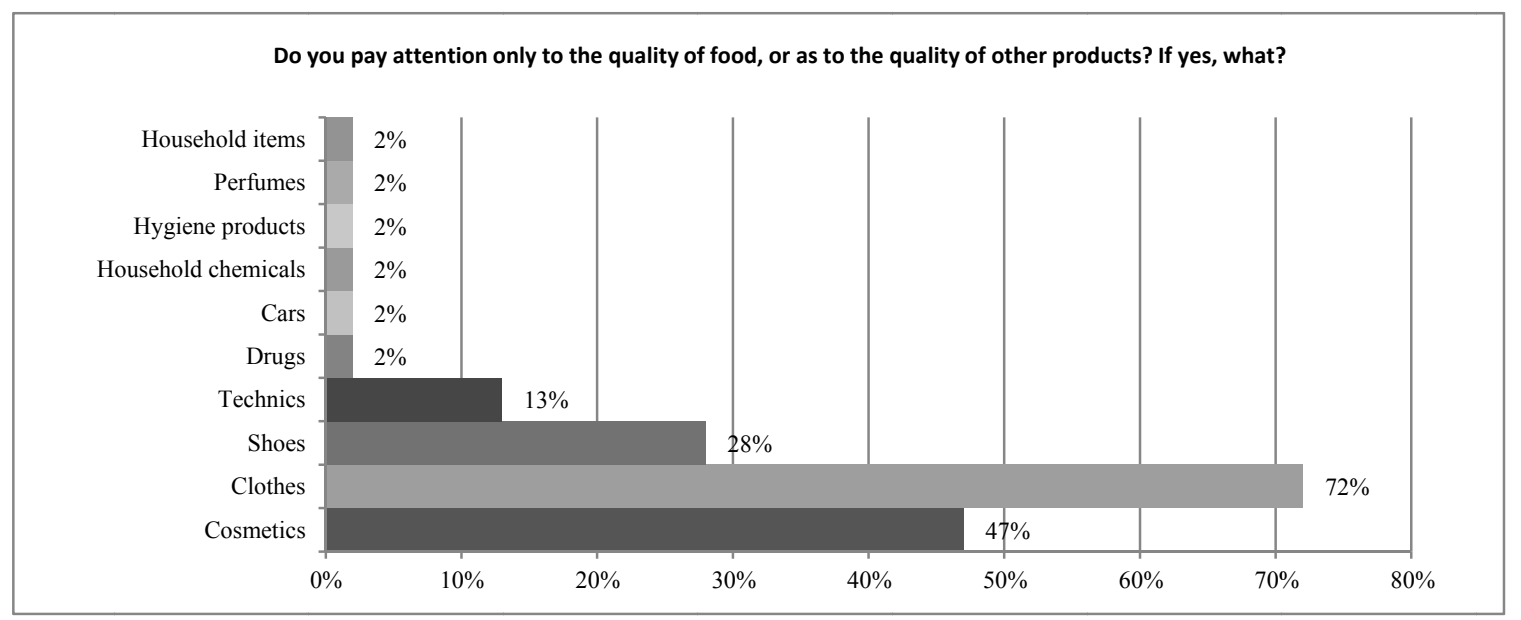

Figure 6. Answers to girls aged 18 to 30 years to the question "Do you pay attention only to the quality of food, or as to the quality of other products? If yes, what?", \%

Thus, we can conclude that the methods and means of promoting almost every group of consumer goods should be based on environmental factors, especially cosmetics, clothes and shoes.

To the question "Do you read the composition of components (substances, materials), which is listed on the product being purchased?" $47 \%$ of respondents answered yes, $50 \%$ said that they sometimes read up, and 3\% do not read on the label of the product. This distribution reflects the responses shown in Figure 7.

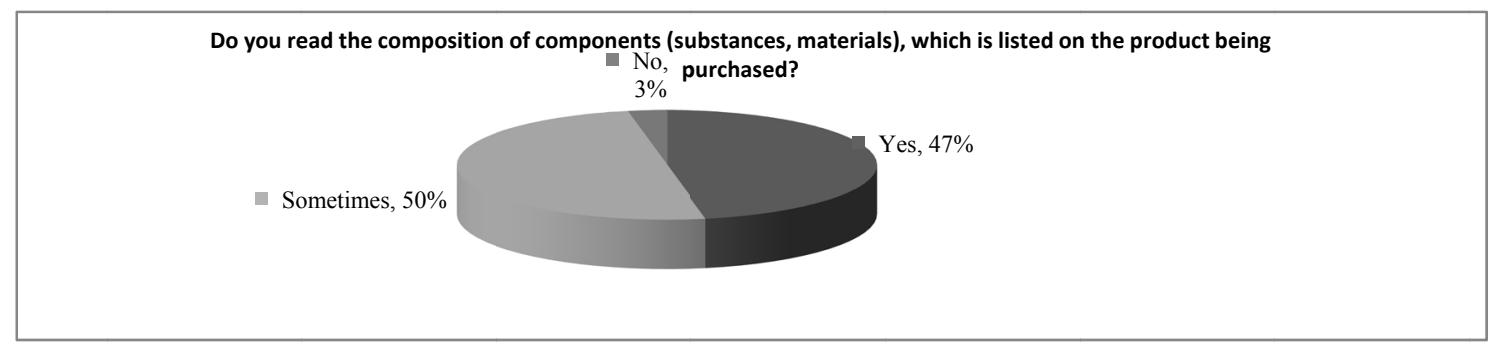


Figure 7. Answers to girls aged 18 to 30 years to the question "Do you read the composition of components (substances, materials), which is listed on the product being purchased?", \%

However, when asked to "pay you attention to the eco-labeled products?" Respondents answered as follows: "yes" - 14\% "sometimes" - 26\% "no" - 17\%, "No, but it is" - 33\%.

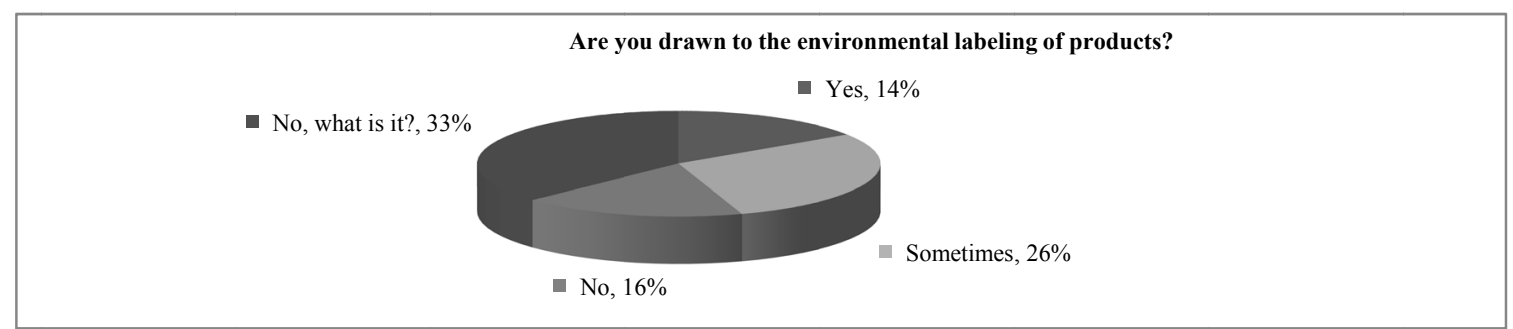

Figure 8. Answers to girls aged 18 to 30 years to the question "Are you drawn to the environmental labeling of products?", \%

Responses are displayed in Figure 8, indicate that $47 \%$ of respondents who read the composition of the product, pay attention to environmental labeling only a third of respondents ( $14 \%$ of all respondents of the respondents). And $33 \%$ of respondents and did not know what the eco-labeling, indicating that the low environmental awareness of modern Russian consumers.

The next set of questions aimed at finding effective means of advertising campaigns on the market of children's goods, to determine the factors that govern the girls while shopping, and the identification of possible motivational factors that may be used when promoting children's products.

To the question "Where are you most likely to commit their purchases?". Answers were distributed as follows in Figure 9: 57\% of respondents make purchases online grocery shopping" MAN ", 33\% - in the grocery chain of "Magnit", 28\% - in the online grocery stores "Pyaterochka", 8\% - in the network thrifty stores "Ruble Boom", 63\% - in the grocery chain "Radezh", 10\% - in the hypermarket METRO Cash \& Carry, 33\% - in a network of hypermarkets "Roundabout" - 33\% hypermarket chain "Okay", 22\% - in the hypermarket "Lenta", 16\% - at fairs, food markets, $0 \%$ - from online stores. There were also own and answered: "in a network of hypermarkets "Real" - 12\%, "hypermarket "Ashan" - 5\%, the store "Gourmet" - 2\% "in the network" Plus" - $4 \%$.

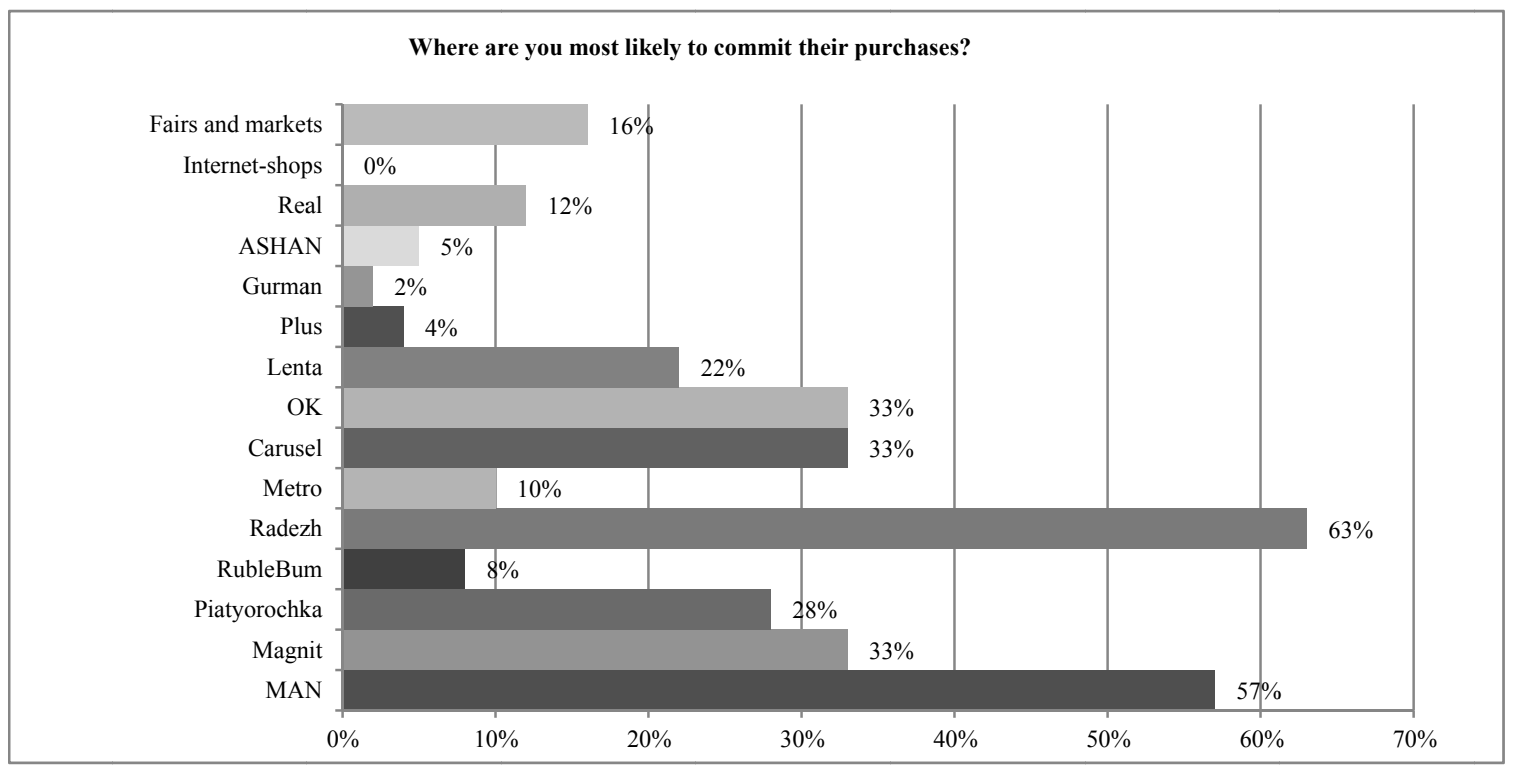

Figure 9. Answers to girls aged 18 to 30 years to the question "Where are you most likely to commit their purchases?", \% 
Thus, the most popular shops are Radezh, MAN, OK, Carousel magnet. Factors influencing the choice of data stores by consumers are a wide range ( $62 \%$ of all respondents surveyed) and convenient location ( $66 \%$ of all respondents of the respondents). Also on store choice is affected by such factors as the qualified staff (3\%), fresh and quality products $(11 \%)$, low prices $(31 \%)$, the presence in the range of natural products (eco-friendly, "bio") (3\%). It can be concluded that the development of Internet-shop need to take into account the key factors shaping the choice of store. And, despite the fact that "the presence in the range of natural products (eco-friendly, "bio")" and "fresh and high quality products," draws attention to a small number of consumers still need to consider this factor. Since ceteris paribus at a convenient location of retail space, a wide assortment of qualified staff, affordable prices will have decisive importance of factors such as fresh, quality products and organic foods, as competition intensifies and intermediaries (traders) have to find new methods and a means of promoting their business and gaining customers. Factors influencing the choice of shopping reflected in Figure 10.

Despite the fact that the survey showed zero interest in online shopping, it does not diminish their appeal. Regional online shopping slow but progressive increase their turnover rate and acquire new customers. Certainly, the success of these stores will depend on the above factors, and the effectiveness of the advertising campaign, the development of which it is necessary to take into account the popularity of shopping stores in the region by selecting the most popular as advertising platforms.

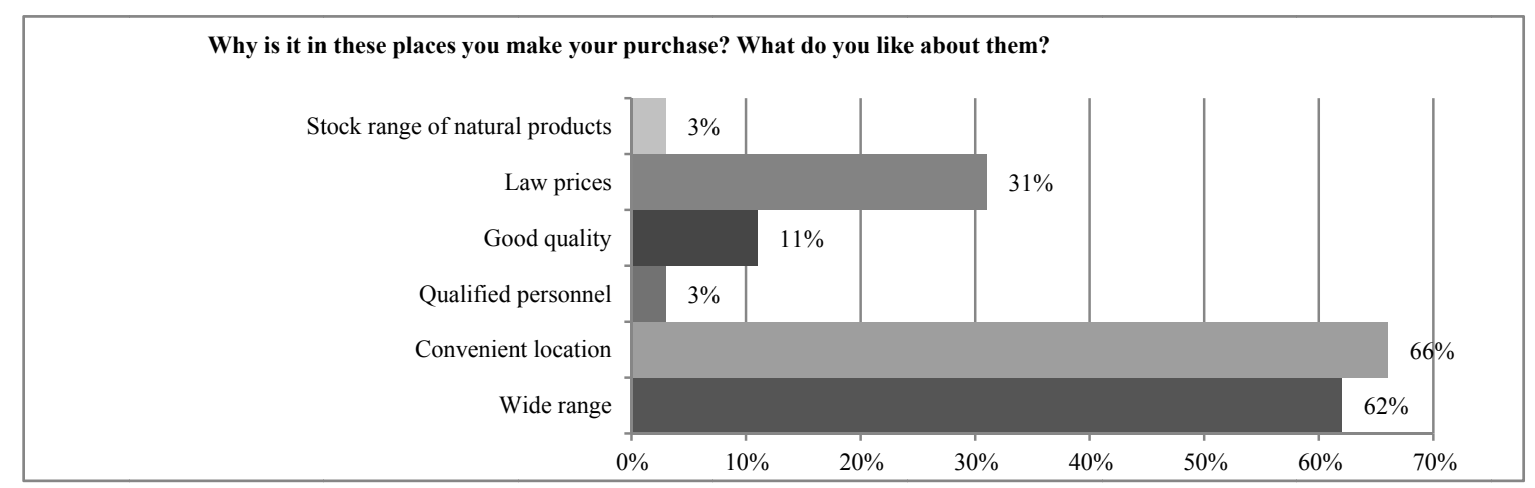

Figure 10. Answers to girls aged 18 to 30 years to the question "Why is it in these places you make your purchase? What do you like about them?", \%

Next, consider how the respondents relate to the fact that environmental goods have higher prices, and whether it is justified. This distribution of responses is shown in Figure 11.

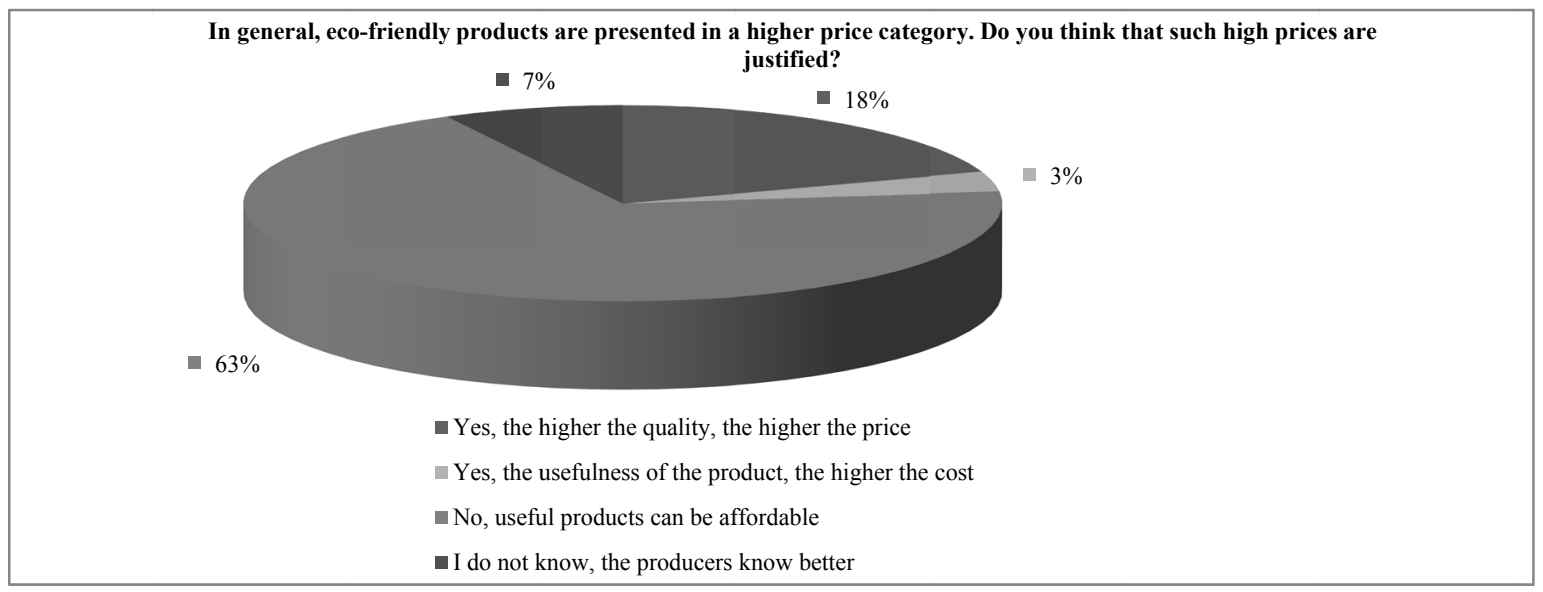

Figure 11. Answers to girls aged 18 to 30 years to the question "In general, eco-friendly products are presented in a higher price category. Do you think that such high prices are justified?", $\%$

The responses showed that most people think that the quality and usefulness of the product is not a factor in increasing the value of the product, so you need to develop an effective pricing policy and competently engage in the promotion of products, justifying the increase in the cost of compelling marketing solutions. 
The next question, "What is the fact you might have to convince yourself to buy your product is environmentally friendly?". Answers were distributed as follows in Figure 12: "the existence of a distinctive sign, approved by special institutions" - 60\% "if the product is local producer" - 18\%, "if advised friends" - 2\%, "composition" $5 \%$, "date of manufacture" - 2\% "if the person has already used" - 2\%, "not interested" - 2\% "if the product has long been market" - 2\%"do not know" - 2\%,"none"- $2 \%$.

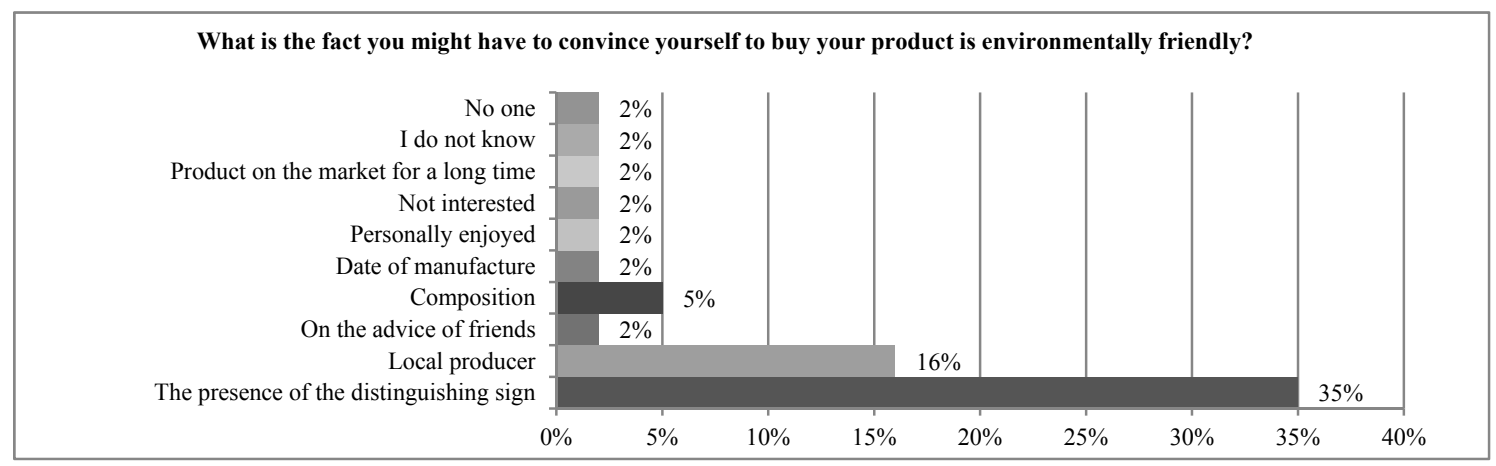

Figure 12. Answers to girls aged 18 to 30 years to the question "What is the fact you might have to convince yourself to buy your product is environmentally friendly?", \%

Thus, the responses indicate that the presence of a distinctive mark convinces the majority of consumers that the product is truly ecological. Therefore, our thesis is that eco-labeling is an effective marketing tool, which is right and demands the implementation in practice.

Based on the answers to the question "What kind of eco-labels do you know?" It is clear that the majority of consumers do not own environmental literacy and do not know no one eco-labeling (33\%), this conclusion is based on the answers that are displayed in Figure $1320 \%$ interviewed respondents know labeled "contains GMO" and $2 \%$ - know the "Blue Angel". The rest of the respondents answered this formulation (GOST - $10 \%$ eco-product - $2 \%$, Eco-label - $2 \%$, W-2\%, green leaves - $2 \%$, tetra-park - 3\%, Bio - 2\%), which allow us to say that consumers are confused about the concept of ecological product. This fact is hindering the development of the market for environmental products.

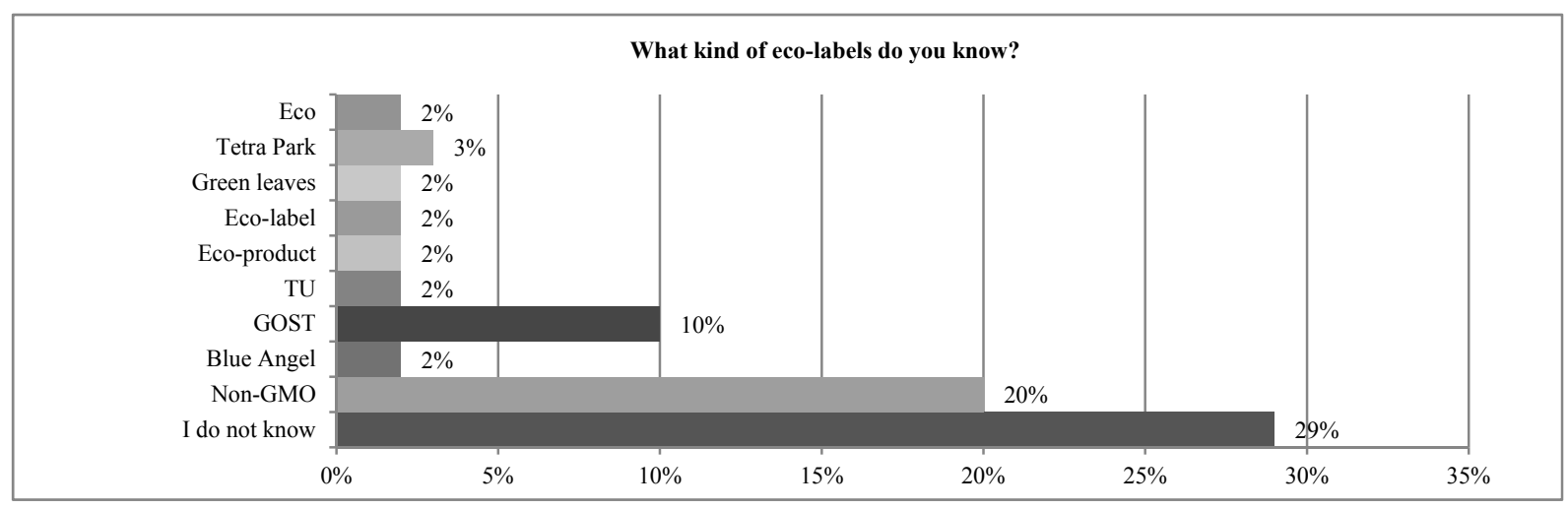

Figure 13. Answers to girls aged 18 to 30 years to the question "What kind of eco-labels do you know?", \%

In the last two issues identified media, most often used by consumers, especially the Internet resources. 


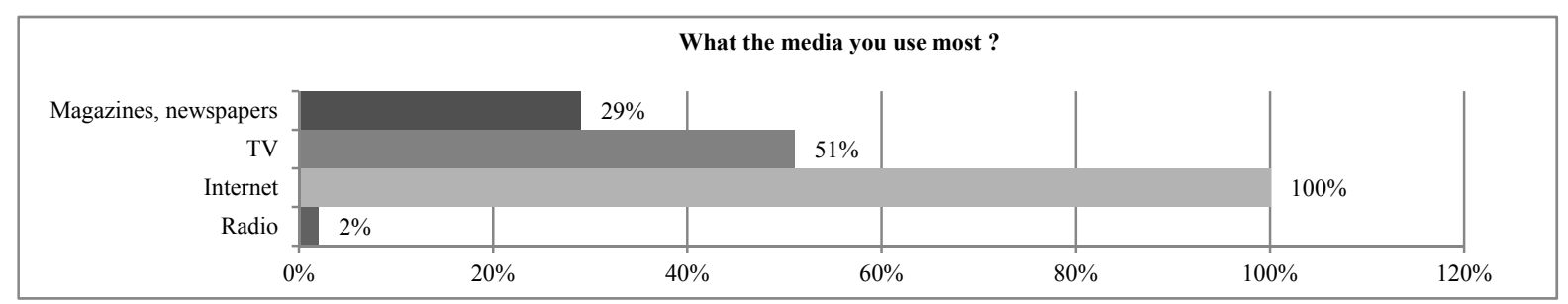

Figure 14. Answers to girls aged 18 to 30 years to the question "What the media you use most?", \%

Responses reflected in Figure 14, shown is the fact that all respondents use the Internet as a means of information (100\%), which should be considered when selecting advertising media planning and marketing strategy to promote. Next in Figure 15-16 represent the detailed answers to the most frequently used Internet resources, among them the most popular are the social networks, in particular social network vkontakte.com $95 \%$.

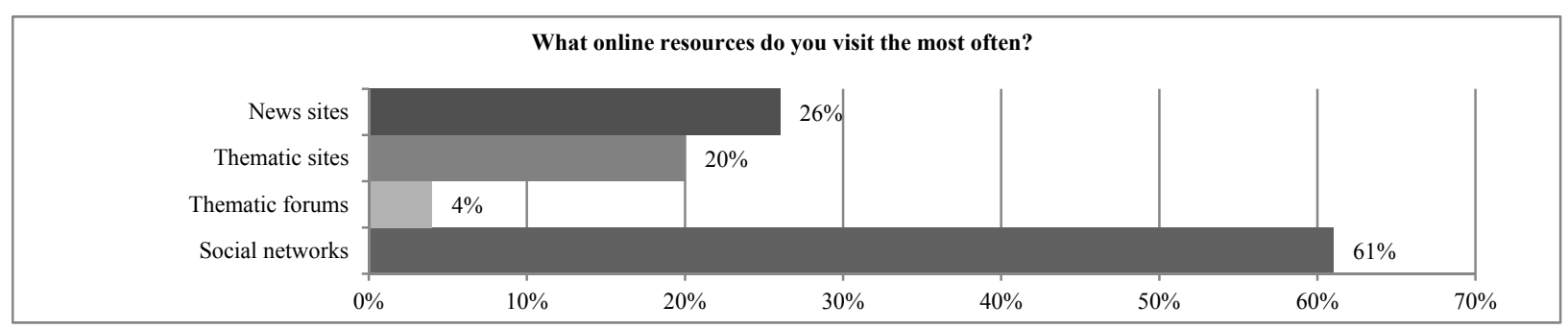

Figure 15. Answers to girls aged 18 to 30 years to the question "What online resources do you visit the most often?", \%

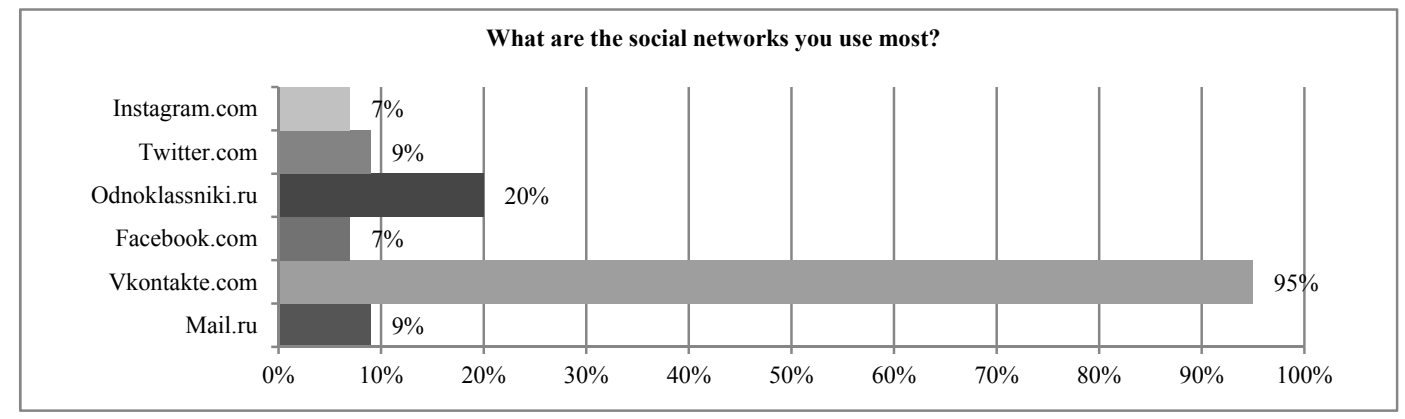

Figure 16. Answers to girls aged 18 to 30 years to the question "What are the social networks you use most?", \%

\section{Discussion}

The presented results of marketing research allow us to find new marketing methods and tools for the business organization of commercial enterprise, using the environmental component of the product as the main instrument. As a result, this will solve the problem of the study, having established a robust infrastructure of the market and increasing the number of high-quality, eco-certified products in the Russian market of children's goods, making it more attractive for the consumer. The main tool for solving this problem is to introduce tools for environmental marketing.

I should say that the authors used static information from secondary sources are relatively cheap and do not provide the specific needs of individual firms. Market research on the state of the market and consumer preferences plays important role for the media. Unfortunately, the Russian market for environmental marketing research there is a demand, but they have not yet received their development. An example of a secondary source of environmental information is the fourth edition of the research report "Market ecological food in Russia and in the world", released marketing agency RBC. research (RBC Department of Consulting) in April 2013 (Anon, 2013). Any company can purchase this publication in order to increase awareness of the environmental market and develop their own environmental strategy. 
However, the first step in the chain of events for promotion of organic products is to monitor consumer preferences of the target audience through marketing research. Using the algorithm developed for monitoring consumer preferences, the main activities of which are the "development of the questionnaire, the questionnaire", "choice of research", "scheduling research", "definition of quota sampling study", "a study", "presentation of the results" may be carried out regular collection and analysis of information on the state of media and marketing on consumers in terms of their behavior, attitudes and intentions. Information about changes in the dynamics of the observed parameters provide a basis for the restructuring of the complex environmental marketing.

\section{Conclusion}

Thus, through a survey of females aged 18 to 30 years identified a number of factors shaping consumer behavior in the market of organic products, the attitude of the modern mass market to producers of organic products, the nature of the relationship of consumers and producers in the market, the level of environmental awareness of the Russian population.

The main conclusions that are of particular scientific value:

1. Sports-oriented girls choose healthy foods.

2. Environmental factor when choosing products for their diet is little conclusive, but still the quality of products affects the choice of products, in order to maintain good health, and therefore the environmental factor in the long term is to expand its necessity.

3. Products without additives and dyes are of interest to consumers, which is of particular value in our study, since naturalness is the main feature of ecological products.

4. "Healthy Eating" is associated with environmental products, so you can definitely use the environmental factor in the promotion of food to children.

5. The majority of consumers care about the quality of not only food, but also some other products (cosmetics, clothes, shoes, electronics, medicine, machinery, household cleaning products, personal hygiene products, perfumes, household items), suggesting the need for promotion of almost every consumer group products based on environmental factors, especially cosmetics, clothes and shoes.

6. The majority of consumers who read the composition of the product, pay attention to eco-labeling. But there are those who do not know what the eco-labeling, indicating that the low environmental awareness of modern Russian consumers.

7. Despite the fact that "the presence in the range of natural products (eco-friendly," bio ")" and "fresh and high quality products," draws attention to a small number of consumers still need to consider this factor. Since ceteris paribus at a convenient location of retail space, a wide assortment of qualified staff, affordable prices will have decisive importance of factors such as fresh, quality products and organic foods, as competition intensifies and intermediaries (traders) have to find new methods and a means of promoting their business and gaining customers.

8. Despite the fact that the survey showed zero interest in online shopping, it does not diminish their appeal. Regional stores slow but progressive pace increase their speed and gain new customers. Certainly, the success of these stores will depend on the above factors, and the effectiveness of the advertising campaign, the development of which it is necessary to take into account the popularity of shopping stores in the region by selecting the most popular as advertising platforms.

9. Responses showed that most people believe that the quality and usefulness of the product is not a factor in increasing the value of the product, so you need to develop an effective pricing policy and competently engage in the promotion of products, justifying the increase in the cost of compelling marketing solutions.

10. The presence of the distinguishing sign convinces the majority of consumers that the product is truly ecological. Therefore, our thesis is that eco-labeling is an effective marketing tool, which is right and demands the implementation in practice.

11. The majority of consumers do not own environmental literacy and do not know no one eco-labeling, which is a deterrent to the development of the market for environmental products.

12. All consumers use the Internet as a means of information that need to be considered when choosing advertising media planning and marketing strategy to promote. The most commonly used Internet resource are social networks, in particular social network vkontakte.com. 


\section{Acknowledgements}

This work was financially supported by the Ministry of Education and Science of the Russian Federation within the basic part of government order (Project \# 2797).

Special thanks go to the director of marketing agency "Marka" Popkova Elena Gennadievna, doctor of economic sciences, professor Volgograd State Technical University for their assistance in conducting marketing research, namely successfully implemented recruitment of respondents and the provision of modern technical means.

\section{References}

Akopova, E. S., Popkova, E. G., Alehina, E. S., Dubova, Y. I., Popova, J. N., Avdeev, I. A., \& Proskurina, I. Y. (2013). Methodology of development of strategy of development of economic systems. World Applied Sciences Journal, 26(4), 489-493.

Anon. (2009). GrIs green marketing Responsible Marketing? Retrieved February 1, 2013, from $\mathrm{http}$ ://responsiblemarketing.com/blog/2009/02/16/is-green-marketing-responsible-marketing

Anon. (2013). Green Paper. Retrieved March 10, 2013, from http://zelenayakniga.ru/sites/default/files/3_ preface_0.pdf

Anon. (2013). Market ecological food products in Russia and in the world. Retrieved July 2, 2013, from http://marketing.rbc.ru/research/562949986744935.shtml

Anon. (2013). Online kids' store «Galaktiika.ru». Retrieved July 2, 2013, from http://galaktiika.ru/

Borodin, A. (2004). The marketing mechanism for the implementation of environmental and economic policies. Marketing, 5, 35-47.

Budanov, I. M., Popkova, E. G., Akopova, E. S., \& Natsubidze, A. S. (2013). The directions of transition of economic systems to new quality of economic growth. World Applied Sciences Journal, 26(9), 1180-1184.

Dahlstrom, R. (2010). Green Marketing Management (p. 360). Cengage Learning.

Grant, J. (2007). The Green Marketing Manifesto (p. 320). Wiley.

Harkova, N. N., Volosatova, U. A., Rossinskaya, M. V., \& Sidorenko, A. S. (2014). Peculiarities of Environmental Certification on the Russian Market. World Applied Sciences Journal, 30(3), 381-383.

Kotler, A. F., \& Keller, K. L. (2007). Marketing Management (p. 816). St. Petersburg. Peter.

Leonard, A. (2010). The Story of Stuff: How Our Obsession with Stuff is Trashing the Planet, Our Communities, and Our Health and a Vision for Change (p. 352). Simon \& Schuster Canada.

Popkova, E. G., \& Tinyakova, V. I. (2013). Dialectical Methodology of Analysis of Economic Growth. World Applied Sciences Journal, 24(4), 467-475.

Popkova, E. G., Shahovskaya, L. S., Volosatova, U. A., Ostrovskaya, V. N., \& Ponomareva, L. V. (2014). Economic efficiency management of the marketing activity of an ecology-oriented company. Life Science Journal, 11(12), 180-184.

Volosatova, W. A., Shvagerus, P. V., Popkova, E. G., \& Budanov, I. M. (2014). Conceptual Approach to Ecological Information Marketing System Formation at the Russian Market. World Applied Sciences Journal, 30(8), 1020-1023.

\section{Copyrights}

Copyright for this article is retained by the author(s), with first publication rights granted to the journal.

This is an open-access article distributed under the terms and conditions of the Creative Commons Attribution license (http://creativecommons.org/licenses/by/3.0/). 